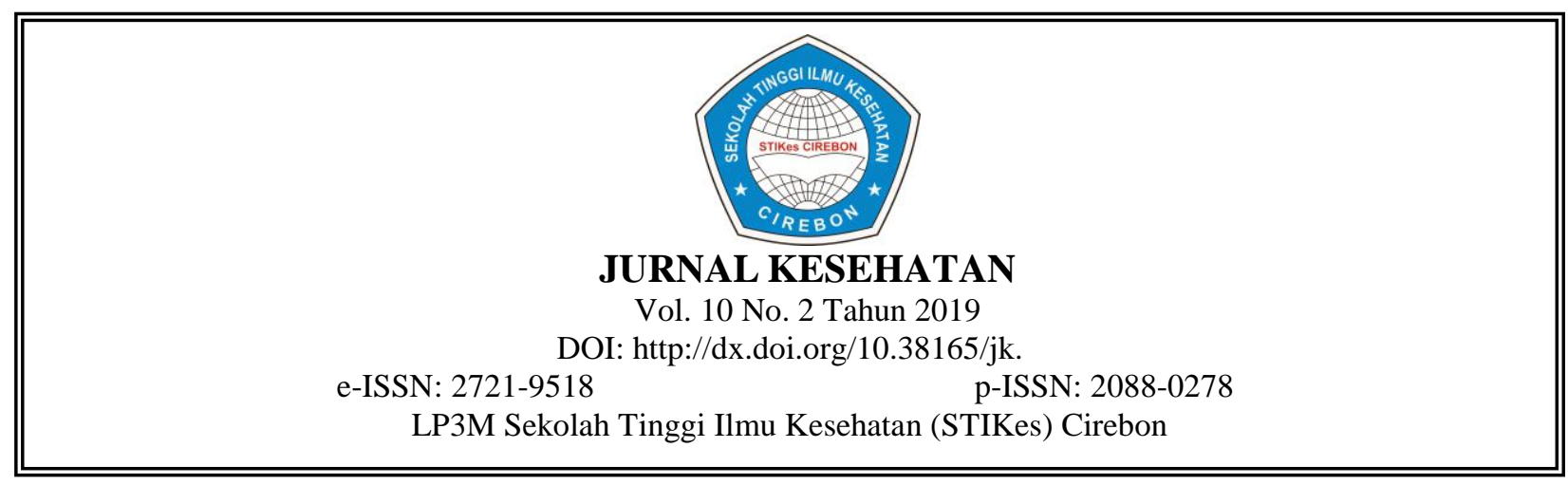

\title{
PENGARUH PENDIDIKAN KESEHATAN TERHADAP TINGKAT PENGETAHUAN REMAJA TENTANG HIV/AIDS
}

\author{
Ira Faridasari* \\ Program Studi Ilmu Keperawatan Sekolah Tinggi Ilmu Kesehatan Cirebon \\ ira_faridasari@yahoo.com
}

\begin{abstract}
Abstrak
HIV/AIDS merupakan salah satu masalah kesehatan di dunia yang sangat mengkhawatirkan dan mengancam kehidupan di karenakan sampai saat ini belum ada obat yang dapat menyembuhkan penyakit HIV/AIDS. Tingginya angka kejadian HIV/AIDS dianggap berhubungan dengan rendahnya pengetahuan mengenai HIV/AIDS. Pendidikan kesehatan pada remaja diperlukan untuk mencegah terjadinya penyakit HIV/AIDS. Tujuan penelitian ini adalah untuk mengetahui pengaruh pendidikan kesehatan terhadap tingkat pengetahuan remaja tentang HIV/AIDS di MA Pringgabaya Kabupaten Indramayu Tahun 2019. Jenis penelitian yang digunakan adalah jenis penelitian kuantitatif dengan menggunakan rancangan penelitian pre-eksperimental dengan one-group pretest- posttest design tanpa kelompok kontrol. Populasi dalam penelitian ini adalah kelas X-XI MA Pringgabaya Kabupaten Indramayu yang terdiri dari 90 remaja. Sampel diambil dengan teknik total sampling, sehingga jumlah responden 90 responden. Teknik analisa data yang digunakan adalah uji Paired Sampel T Test. Hasil penelitian menunjukkan pengetahuan responden sebelum diberikan intervensi pendidikan kesehatan menunjukkan nilai rata-rata 60,90 dan sesudah diberikan intervensi pendidikan kesehatan menunjukkan rata-rata 85,16. Hasil uji statistik menggunakan uji Paired Samples T Test menunjukkan bahwa Asymp. Sig yang diperoleh sebesar $0,000 \mathrm{a}<0,05$, maka Ho ditolak, berarti terdapat perbedaan pendidikan kesehatan terhadap tingkat pengetahuan remaja tentang HIV/AIDS.
\end{abstract}

Kata Kunci: HIV/AIDS, pendidikan kesehatan, remaja

\begin{abstract}
HIV/AIDS is one of the health problems in the world that is very worrying and threatening life because until now there is no cure for HIV/AIDS. The high rate of HIV/AIDS is considered to be associated with low knowledge about HIV / AIDS. Health education in adolescents is needed to prevent the occurrence of HIV/AIDS. The purpose of this study was the effect of health education on the level of knowledge of adolescents about HIV/AIDS in MA Pringgabaya in Indramayu District in2019. The type of research used is a type of quantitative research using a pre-experimental study design design with one-group pretest-posttest design without a control group. The population in this study was class $X$ XI MA Pringgabaya Indramayu Regency consisting of 90 adolescents. The sample is taken by the Total Sampling technique, so the number of respondents is 90 respondents. The data analysis technique used is the Paired Sample T Test.The results showed that the knowledge of respondents before being given a health education intervention showed an average value of 60.90 and after being given a health education intervention it showed an average of 85.16. The results of statistical tests using the Paired Samples T Test show that Asymp. Sig obtained is 0,000 a <0,05, so Ho is rejected and Ha is accepted, meaning there is a difference inhealth education to the level of adolescent knowledge about HIV/AIDS.
\end{abstract}

Keywords: HIV/AIDS, health education, adolescent 


\section{PENDAHULUAN}

HIV (Human Immunodeficiensy Virus) adalah virus yang menyerang sistem kekebalan tubuh manusia dan melemahkan kemampuan tubuh untuk melawan berbagai jenis penyakit. AIDS (Acquired Immune Deficiensy Syndrome), sebenarnya bukan suatu penyakit tetapi merupakan kumpulan dari gejala-gejala penyakit yang disebabkan oleh infeksi berbagai macam organisme serta keganasan lain yaitu turunnya daya tahan tubuh penderita. HIV menyerang dan merusak sel-sel limfosit T yang mempunyai peran penting dalam sistem kekebalan seluler. ${ }^{1}$

Penyakit AIDS pertama kali ditemukan pada tahun 1981 di Amerika Serikat yang kemudian dengan pesatnya menyebar ke seluruh dunia. Di negara - negara Amerika Latin dilaporkan 7.215 kasus AIDS melanda kaum muda berusia 20-49 tahun yang sebagian besar adalah kaum homoseksual dan pengguna obat-obat suntik ke pembuluhdarah. ${ }^{2}$

Berdasarkan laporan UNAIDS di Asia dan Pasifik tahun 2017, 5,2 juta orang diperkirakan hidup dengan HIV/AIDS. Sedangkan negara - negara di Asia yang disebut - sebut berada pada titik bahaya infeksi HIV yaitu India, Indonesia dan China. Di Indonesia kasus epidemik penyakit ini masih terus meningkat, meskipun jumlah infeksi baru menunjukkan penurunan besar dalam infeksi HIV di Kamboja, India, Myanmar, Thailand, dan Vietnam. ${ }^{3}$

Indonesia merupakan salah satu Negara berkembang di wilayah Asia yang telah digolongkan menjadi Negara dengan tingkat epidemik yang terkonsentrasi atau concentrated level epidemic (CLE) karena memiliki kantong - kantong epidemik dengan prevalensi lebih dari 5\% pada subpopulasi beresiko terinfeksi HIV seperti pekerja seks komersial cukup besar. Perkembangan kasus HIV/AIDS di Indonesia memperlihatkan peningkatan yang semakin pesat. Kasus HIV/AIDS di Indonesia ditemukan pertama kali pada tahun 1987 dan jumlah kasus AIDS sampai dengan Desember 2017, HIV/AIDS telah dilaporkan oleh $421(81,9 \%)$ dari 51 kabupaten/kota diseluruh provinsi di Indonesia. Secara kumulatif, jumlah penderita AIDS yang dilaporkan sampai Desember 2017 sebanyak 102.667 orang. ${ }^{4}$

Berdasarkan data Dinas Kesehatan Kabupaten Indramayu pada tahun 2017 menyebutkan jumlah penderita HIV/AIDS tercatat 477 orang. ${ }^{5}$

Berdasarkan data Dinas Kesehatan Kabupaten Indramayu pada tahun 2017 menyebutkan jumlah penderita HIV/AIDS tercatat 477 orang. ${ }^{5}$ Sedangkan menurut data Komisi Penanggulangan AIDS (KPA) Indramayu menyebutkan mulai tahun 1993 sampai September 2018 pengidap HIV/AIDS secara keseluruhan mencapai 3.285 orang yakni AIDS sebanyak 1.862 orang dan HIV sebanyak 1.422 orang.

Hasil studi pendahuluan melalui wawancara yang dilakukan pada beberapa guru, diperoleh informasi bahwa belum ada sosialisasi atau pendidikan kesehatan HIV/AIDS yang diberikan pada siswa serta belum ada pembelajaran tentang HIV/AIDS. Sedangkan berdasarkan survei awal yang dilakukan oleh peneliti pada 15 siswa diperoleh informasi bahwa 10 siswa tidak mengetahui tentang HIV/AIDS dan 5 siswa sudah mengetahui tentang HIV/AIDS tetapi masih memiliki pengetahuan yang kurang tentangHIV/AIDS.

Tujuan penelitian ini adalah untuk Mengetahui pengaruh pendidikan kesehatan terhadap tingkat pengetahuan remaja tentang HIV/AIDS.

\section{METODE PENELITIAN}

Penelitian ini adalah penelitian kuantitatif, dengan menggunakan metode penelitian preeksperimental dengan one-group pretest-posttest design tanpa kelompok kontrol. Populasi dalam penelitian ini adalah siswa/siswi kelas X-XI yang berjumlah 90 siswa. Pengambilan sampel dilakukan menggunakan teknik total sampling. Metode pengumpulan data dalam penelitian ini menggunakan teknik wawancara, dan instrumen yang digunakan adalah kuesioner. Analisa univariat dilakukan untuk menggambarkan distribusi frekuensi masing-masing variabel baik variabel bebas maupun variabel terikat, dan analisa bivariat yang digunakan uji Paired Samples T Test 


\section{HASIL PENELITIAN \\ Karakteristik Responden}

Tabel 1. Distribusi responden menurut jenis kelamin, usia dan sumber pengetahuan remaja tentang penyakit HIV/AIDS

\begin{tabular}{|c|c|c|c|}
\hline No & Karakteristik & $\mathrm{n}(90)$ & Persentase $(\%)$ \\
\hline \multirow[t]{3}{*}{1} & Jenis kelamin & & \\
\hline & Perempuan & 56 & 62,2 \\
\hline & Laki-laki & 34 & 37,8 \\
\hline \multirow[t]{4}{*}{2} & Usia & & \\
\hline & 15 tahun & 24 & 26,7 \\
\hline & 16 tahun & 45 & 50,0 \\
\hline & 17 tahun & 21 & 23,3 \\
\hline \multirow[t]{11}{*}{3} & Sumber pengetahuan & & \\
\hline & Guru & 12 & 13,3 \\
\hline & Orang tua & 2 & 2,2 \\
\hline & Teman & 9 & 10,0 \\
\hline & Koran & 2 & 2,2 \\
\hline & Majalah & 0 & 0 \\
\hline & TV & 10 & 11,1 \\
\hline & Radio & 0 & 0 \\
\hline & Internet & 52 & 57,8 \\
\hline & Buku & 3 & 3,3 \\
\hline & Penyuluhan & 0 & 0 \\
\hline
\end{tabular}

Berdasarkan tabel 1 dapat diketahui dari 90 orang responden sebagian besar berjenis kelamin perempuan sebanyak 62,2\% (56 orang), sebagian besar responden berusia 16 tahun sebanyak 50\% (45 orang), sumber pengetahuan responden tentang penyakit HIV/AIDS sebagian besar mereka dapatkan dari internet sebanyak $57,8 \%$ (52 orang).

\section{Tingkat Pengetahuan}

Tabel 2. Tingkat pengetahuan responden (pre test)

\begin{tabular}{cccc}
\hline No & Kategori & $\mathrm{n}$ & Persentase (\%) \\
\hline 1 & Baik & 7 & 7,8 \\
2 & Cukup & 57 & 63,3 \\
3 & Kurang & 26 & 28,9 \\
\hline & Total & 90 & 100
\end{tabular}

Berdasarkan tabel 2 diatas dapat diketahui bahwa sebelum diberikan pendidikan kesehatan tentang penyakit HIV/AIDS yaitu kategori baik sebanyak 7 responden $(7,8 \%)$, pada kategori cukup sebanyak 57 responden $(63,3 \%)$ dan pada kategori kurang sebanyak 26 responden $(28,9 \%)$.

Tabel 3. Tingkat pengetahuan responden (post test)

\begin{tabular}{llcc}
\hline No & Kategori & $\mathrm{n}$ & Persentase (\%) \\
\hline 1 & Baik & 78 & 86,7 \\
2 & Cukup & 12 & 13,3 \\
3 & Kurang & 0 & 0 \\
\hline & Total & 90 & 100 \\
\hline
\end{tabular}

Tabel 3 menunjukkan bahwa sesudah diberikan pendidikan kesehatan tentang penyakit HIV/AIDS yaitu kategori baik sebanyak 78 responden (86,7\%), pada kategori cukup sebanyak 12 
responden $(13,3 \%)$ dan pada kategori kurang tidak ada $(0)$.

Tabel 4. Perbedaan tingkat pengetahuan responden pre test dan post test

\begin{tabular}{ccccccc}
\hline & $\mathrm{N}$ & Min & Mean & Max & SD & P Value \\
\hline $\begin{array}{l}\text { Pre } \\
\text { Test }\end{array}$ & 90 & 37,00 & 61,77 & 80,00 & 9,899 & 0,00 \\
\hline $\begin{array}{l}\text { Post } \\
\text { Test }\end{array}$ & & & & & \\
\hline
\end{tabular}

Berdasarkan tabel 4 dapat diketahui bahwa hasil rata-rata nilai pengetahuan responden tentang penyakit HIV/AIDS pada pre test yaitu sebelum diberikan pendidikan kesehatan adalah 61,77 dengan nilai terendah 37,00 dan nilai tertinggi 80,00. Median 62,00 dengan standar deviasi 9,899. Setelah diberikan intervensi dengan menggunakan pendidikan kesehatan, hasil analisis nilai dapat diketahui pada post test yaitu dengan nilai rata-rata 85,21. Nilai terendah 70,00 dan nilai tertinggi 100,00. Median 83,00 dengan standar deviasi 7,774. Data diatas menggambarkan bahwa terjadi perubahan pada peningkatan nilai rata-rata pada pengetahuan responden setelah diberikan intervensi pendidikan kesehatan tentang penyakit HIV/AIDS.

\section{PEMBAHASAN}

\section{Pengetahuan Sebelum Diberikan Pendidikan Kesehatan tentang Penyakit HIV/AIDS}

Pengetahuan responden tentang penyakit HIV/AIDS sebelum diberikam intervensi pendidikan kesehatan menunjukkan nilai rata-rata yaitu $61,77 \%$. Nilai rata- rata menunjukkan bahwa sebagian besar responden mempunyai pengetahuan yang cukup tentang HIV/AIDS 63,3\% (57 responden) dan sebagian kecil lainnya yaitu 7,8\% (7 reponden) memiliki pengetahuan yang baik dan $28,9 \%$ (26 responden) memiliki pengetahuan yang kurang. Pengetahuan adalah segala upaya yang direncanakan untuk mempengaruhi orang lain baik individu, kelompok atau masyarakat sehingga mereka melakukan apa saja yang diharapkan oleh perilaku pendidikan pengetahuan atau kognitif merupakan dominan yang sangat penting untuk terbentuknya tindakan seseorang. ${ }^{7}$

Pengetahuan dipengaruhi oleh faktor pendidikan formal. Pengetahuan hubungannya sangat erat dengan pendidikan, dimana diharapkan bahwa pendidikan yang tinggi maka orang tersebut akan semakin luas pengetahuannya. Faktor pengetahuan yang lainnya dalam pengetahuan responden tentang penyakit HIV/AIDS yaitu sumber informasi yang didaptkan oleh responden yang bersal dari internet, orang tua, guru ataupun petugas kesehatan.

\section{Pengetahuan Sesudah Diberikan Pendidikan Kesehatan tentang Penyakit HIV/AIDS}

Pengetahuan responden tentang penyakit HIV/AIDS sesudah diberikan intervensi pendidikan kesehatan menunjukkan nilai rata-rata yaitu $85,21 \%$. Nilai yang didapatkan setelah diberikan pendidikan kesehatan lebih besar dari sebelum diberikan pendidikan kesehatan. Hal ini menunjukkan bahwa terdapat peningkatan pengetahuan tentang penyakit HIV/AIDS sebelum dan sesudah diberikan pendidikan kesehatan. Dari hasil penelitian yang didapatkan memiliki perbedaan nilai yang signifikan.

Hasil penelitian yang dilakukan Sartika Halid (2014) sejalan dengan penelitian ini bahwa terdapat peningkatan nilai yang signifikan antara sebelum dan sesudah diberikan intervensi pendidikan kesehatan. Sebelum diberikan pendidikan kesehatan $62,65 \%$ responden yang dalam kategori pengetahuan kurang, 35,71\% responden dengan kategori pengetahuan cukup dan 1,79\% responden dalam pengetahuan baik. Sedangkan sesudah diberikan intervensi pendidikan kesehatan yaitu 5,38\% responden yang dalam kategori kurang, 75\% responden dalam kategori cukup dan $19,61 \%$ responden dalam kategori baik.

Meningkatnya pengetahuan responden disebabkan pendidikan kesehatan yang telah diberikan. Dan banyak faktor yang mempengaruhi pengetahuan responden tentang penyakit 
HIV/AIDS yaitu pengalaman, pendidikan, sosial budaya dan keyakinan. Pengetahuan dapat diperoleh melalui proses belajar yang terjadi dimana saja dan kapan saja. Sifat khas dari belajar adalah memperoleh suatu yang baru yang dulu sebelum diketahui sekarang diketahui, yang dulu belum mengerti sekarang dimengerti. Jadi pengetahuan adalah hasil "tahu" dan ini terjadi setelah orang melakukan pengindraan terhadap obyek tertentu. Pengindraan terjadi melalui panca indra manusia yaitu indra penglihatan, pendengaran, penciuman, rasa dan raba. Pada waktu penginderaan sampai menghasilkan pengetahuan tersebut sangat dipengaruhi oleh intensitas perhatian persepsi terhadap objek. Sebagian besar pengetahuan manusia diperoleh melalui mata dan telinga. ${ }^{6}$

\section{Perbedaan Pengetahuan Sebelum dan Sesudah Diberikan Pendidikan Kesehatan tentang Penyakit HIV/AIDS}

Berdasarkan hasil pada penelitian ini nilai rata-rata pengetahuan responden tentang penyakit HIV/AIDS pada pre test adalah 61,77\% dengan standar deviasi 9,899. Sedangkan pada post test nilai rata-rata pengetahuan responden $85,21 \%$ dengan standar deviasi 7,774 . Hasil uji Paired Samples T Test didapatkan nilai P atau Sig $=0.00(<0.05)$, maka dapat disimpulkan bahwa terdapat perbedaan yang signifikan antara pengetahuan sebelum dan sesudah diberikan intervensi pendidikan kesehatan tentang HIV/AIDS.

Dalam penelitian yang yang telah dilakukan oleh Ricca Anggareyni (2014) yang berjudul Pengaruh pemberian pendidikan kesehatan terhadap tingkat pengetahuan siswa mengenai HIV/AIDS di SMP PGRI 02 Singkawang. Didapatkan hasil bahwa terdapat peningkatan pengetahuan yang signifikan antara tingkat pengetahuan sebelum dan tingkat pengetahuan sesudah diberikan intervensi pendidikan kesehatan mengenai HIV/AIDS. ${ }^{6}$

Pendidikan mempunyai pengaruh dalam suatu proses belajar, semakin tinggi pendidikan seseorang maka akan semakin mudah orang tersebut untuk menerima informasi. Dengan pendidikan yang tinggi orang akan cenderung untuk mendapatkan informasi, baik dari orang lain maupun dari media massa. Semakin banyak informasiyang diterima maka semakin banyak juga pengetahuan seseorang yang didapatkan tentang penyakit HIV/AIDS.

Pendidikan kesehatan sebagai bagian dari promosi kesehatan yang diperlukan sebagai upaya dalam meningkatkan kesadaran dan pengetahuan, maka hal tersebut diperlukan dalam upaya penyediaan dan penyampaian informasi dalam bentuk penyuluhan atau pendidikankesehatan. Bertambahnya usia anak hingga mengalami masa transisi menuju dewasa yang biasa disebut pubertas, maka akan bertambah juga pengetahuan terhadap kesehatan.

\section{SIMPULAN}

1. Dari hasil penelitian dapat disimpulkan bahwa pengetahuan responden tentang penyakit HIV/AIDS sebelum diberikan intervensi pendidikan kesehatan menunjukkan nilai terendah 37,00 dan nilai tertinggi 80,00 dengan nilai rata- rata 61,77 dan $7,8 \%$ (7 responden) yang termasuk dalam kategori baik.

2. Dari hasil penelitian dapat disimpulkan bahwa pengetahuan responden tentang penyakit HIV/AIDS sesudah diberikan intervensi pendidikan kesehatan menunjukkan nilai terendah 70,00 dan nilai tertinggi 100,00 dengan nilai rata- rata 85,21 dan 86,7\% (78 responden) yang termasuk dalam kategori baik.

3. Hasil uji statistic menggunakan uji Paired Samples T Test menunjukkan bahwa Asymp. Sig yang diperoleh sebesar 0,000 a $<0,05$, maka Ho ditolak. Dengan demikian dapat disimpulkan bahwa terdapat perbedaan pendidikan kesehatan terhadap tingkat pengetahuan remaja tentang HIV/AIDS di MA Pringgabaya Kabupaten Indramayu.

\section{DAFTAR PUSTAKA}

1. Kemenkes RI. Pusat Data dan Informasi Kementrian Kesehatan, Situasi dan analisis HIV/AIDS;2014

2. UNAIDS. Global Report: UNAIDS report on the global AIDS epidemic 2018. Geneva: Joint 
United Nations Programme on HIV/AIDS;2017.

3. P2P Dinkes Indramayu. Kasus HIV- AIDS, Indramayu: Dinas Kesehatan Indramayu;2017

4. Arikunto, S. Prosedur penelitian suatu pendekatan praktek. Jakarta: Rineka Cipta;2010.

5. Sarwono, S. Psikologi remaja. Jakarta: Erlangga;2011

6. Wawan, A., Dewi, M. Teori \& pengukuran pengetahuan sikap dan perilaku manusia, Yogyakarta : NuhaMedika;2010

7. Komisi penanggulangan AIDS. Strategi nasional penanggulangan HIV dan AIDS 2007-2010. Jakarta: Komisi Penanggulangan AIDS Nasional;2007 